Article

\title{
Ring Opening Metathesis Polymerization of Norbornene and Derivatives by the Triply Bonded Ditungsten Complex $\mathrm{Na}\left[\mathrm{W}_{2}(\mu-\mathrm{Cl})_{3} \mathrm{Cl}_{4}(\mathrm{THF})_{2}\right] \cdot(\mathrm{THF})_{3}$
}

Dedicated to my research colleagues at Sir G. Wilkinson's Laboratory (1972-1980).

\section{Georgios Floros ${ }^{1}$, Nikolaos Saragas ${ }^{1}$, Patrina Paraskevopoulou ${ }^{1}$, Nikolaos Psaroudakis ${ }^{1}$, Spyros Koinis ${ }^{1}$, Marinos Pitsikalis ${ }^{2}$, Nikos Hadjichristidis ${ }^{2}$ and Konstantinos Mertis ${ }^{1, *}$}

1 Department of Inorganic Chemistry, Faculty of Chemistry, University of Athens,

Panepistimioupoli Zographou, Athens 15771, Greece; E-Mails: geofloros@chem.uoa.gr (G.F.); nsaragas@sch.gr (N.S.); paraskevopoulou@chem.uoa.gr (P.P.); psaroudakis@chem.uoa.gr (N.P.); koinis@chem.uoa.gr (S.K.)

2 Department of Industrial Chemistry, Faculty of Chemistry, University of Athens,

Panepistimioupoli Zographou, Athens 15771, Greece; E-Mails: pitsikalis@chem.uoa.gr (M.P.); hadjichristidis@chem.uoa.gr (N.H.)

* Author to whom correspondence should be addressed; E-Mail: cmertis@chem.uoa.gr (K.M.); Tel.: +30-210-727-4332; Fax: +30-210-727-4782.

Received: 7 October 2012; in revised form: 10 November 2012 / Accepted: 14 November 2012 / Published: 21 November 2012

Abstract: In this study, the reactions of the bimetallic compound $\mathrm{Na}\left[\mathrm{W}_{2}(\mu-\mathrm{Cl})_{3} \mathrm{Cl}_{4}(\mathrm{THF})_{2}\right] \cdot(\mathrm{THF})_{3}\left(\mathbf{1},\left(\mathrm{W}^{-}-\mathrm{W}\right)^{6+}, a^{\prime 2} e^{4}\right)$ with norbornene (NBE) and some of its derivatives (5-X-2-NBE; $\mathrm{X}=\mathrm{COOH}(\mathbf{N B E}-\mathbf{C O O H}), \mathrm{OH}(\mathbf{N B E}-\mathbf{O H}), \mathrm{CN}(\mathbf{N B E}-\mathbf{C N})$, COOMe (NBE-COOMe), $\mathrm{CH}=\mathrm{CH}_{2}$ (VNBE); norbornadiene (NBD)) are described. Complex 1 contains a tungsten-tungsten triple bond, bearing three halide bridges and two labile THF ligands, in a cisoidal relationship along the metal-metal axis. The complex was found to be a highly efficient room temperature homogeneous and heterogeneous unicomponent initiator for the catalytic ring opening metathesis polymerization (ROMP) of most substrates. NBE provides polynorbornene (PNBE) of high molecular weight $\left(M_{\mathrm{w}}\right)$ in high yields, soluble in organic solvents. The reaction proceeds with high cis-stereoselectivity $(80 \%-86 \%$ cis $)$, independently of the reaction conditions. Strongly coordinating pendant groups $(-\mathrm{COOH},-\mathrm{OH},-\mathrm{CN})$ deactivate 1, whereas substrates bearing softer ones $\left(-\mathrm{COOMe},-\mathrm{CH}=\mathrm{CH}_{2}\right)$ are quantitatively polymerized. NBD gives 
quantitatively insoluble PNBD. The polymers have been characterized by ${ }^{1} \mathrm{H},{ }^{13} \mathrm{C}$ NMR and Size Exclusion Chromatography (SEC). Monitoring the reactions in situ by ${ }^{1} \mathrm{H}$ NMR (1/NBD or NBE) provides direct evidence of the metathetical nature of the polymerization with the observation of the active tungsten alkylidene propagating polymeric chains. Mechanistic aspects of the reactions are discussed.

Keywords: catalysis; metal-metal bonds; norbornenes; ROMP; tungsten

\section{Introduction}

The olefin metathesis reaction induces the mild cleaving and redistribution of carbon-carbon double bonds, and ever since its discovery, it has been highly utilized in polymer science and organic synthesis (basic chemicals, pharmaceuticals) [1-6]. Important classes of olefin metathesis reactions involve the ring closing metathesis (RCM), ring opening metathesis (ROM), and ring opening metathesis polymerization (ROMP). The last one in particular, apart from being a versatile tool for organic synthesis, is the key process for the preparation of various industrial polyalkenamers [7].

Although the ROMP of bicyclo[2.2.1]hept-2-ene (norbornene, NBE) and its derivatives (e.g., bicyclo[2.2.1]hepta-2,5-diene, norbornadiene, NBD), providing polynorbornene (PNBE) and polynorbornadiene (PNBD), respectively (Scheme 1), has been studied for many years and the number of publications is tremendous, the area is still full of challenges [8].

Scheme 1. Ring Opening Metathesis Polymerization (ROMP) of NBE and NBD.
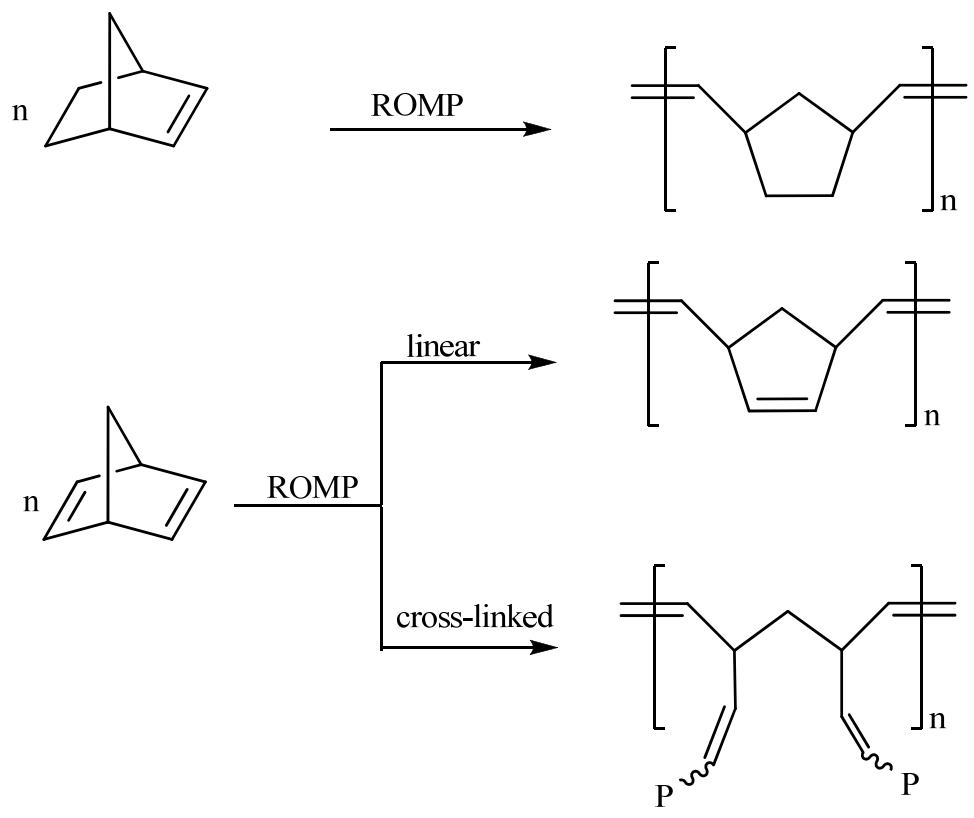

The reaction is catalyzed by a broad range of uni-, bi-, ternary, quaternary and multicomponent catalytic systems based mainly on mononuclear transition metal complexes along the periodic table ( $\mathrm{Ti}, \mathrm{Nb}, \mathrm{Ta}, \mathrm{Cr}, \mathrm{Mo}, \mathrm{W}, \mathrm{Re}, \mathrm{Co}, \mathrm{Ru}, \mathrm{Os}$ ) [1-6]. Among them, protagonists are those of ruthenium, 
molybdenum and tungsten. For the last two, the following major categories have been classified [1-6,9-11]:

(i) ill-defined systems, including the classical high oxidation state halides (e.g., $\mathrm{MoCl}_{5}, \mathrm{WCl}_{6}$ ), oxohalides (e.g., $\mathrm{WOCl}_{4}$ ), alkoxohalides (e.g., $\left[(\mathrm{RO})_{x} \mathrm{WCl}_{6-x}\right], x=1-3$ ) and oxoclusters (e.g., $\left[\mathrm{W}_{6} \mathrm{O}_{19}\right]^{2-}$ ) exhibiting small to moderate activity; these become very reactive when activated by organometallic cocatalysts (e.g., $\mathrm{SnMe}_{4}, \mathrm{AlEt}_{3}$ );

(ii) discreet alkylidenes, such as the well-defined $\mathrm{Katz}\left[(\mathrm{OC})_{5} \mathrm{~W}=\mathrm{C}(\mathrm{Ph}) \mathrm{R}\right](\mathrm{R}=\mathrm{OMe}, \mathrm{Ph})[12]$ and Schrock $\left(\left[\mathrm{M}(\mathrm{NAr})(\mathrm{CHR})\left(\mathrm{OR}^{\prime}\right)_{2}\right]\left(\mathrm{M}=\mathrm{Mo}, \mathrm{W} ; \mathrm{Ar}=\right.\right.$ aryl; $\mathrm{R}=$ aryl or alkyl; $\mathrm{R}^{\prime}=\mathrm{CMe}_{3}$, $\left.\mathrm{CMe}_{2} \mathrm{CF}_{3}, \mathrm{CMe}\left(\mathrm{CF}_{3}\right)_{2}, \mathrm{C}\left(\mathrm{CF}_{3}\right)_{3}\right)$ [13] catalysts and their numerous variations.

Despite the abundance of mononuclear catalytic systems, there is only a limited number of bimetallic multiply metal-metal bonded complexes inducing the ROMP of NBE. These include: (a) neutral or ionic complexes containing the $\left(\mathrm{Mo}^{4}{ }^{4} \mathrm{Mo}\right)^{4+}$ core with a variety of ligands (acetate, halide, allyl, acetonitrile) [14], which usually are effective when activated with $\mathrm{Et}_{2} \mathrm{AlCl}$. The different ligands exert little or no influence on the stereoselectivity of the reaction; (b) the $\left[\mathrm{Cp}_{2}{ }_{2} \mathrm{Os}_{2} \mathrm{Br}_{4}\right]\left(\left(\mathrm{Os}^{3} \mathrm{Os}^{6+}\right.\right.$, $\mathrm{Cp}^{*}=\eta^{5}$-pentamethylcyclopentadienyl) compound in the presence of MAO (methylaluminoxane) [15]; and (c) the doubly bonded $\left[\left\{\mathrm{W}\left(\mathrm{NR}^{\prime}\right)\left(\mathrm{OCOMe}{ }_{2} \mathrm{CF}_{3}\right)_{2}\right\}_{2}\left(\mu-\mathrm{C}_{2} \mathrm{H}_{4}\right)\right]\left(\mathrm{R}^{\prime}=2,6-\mathrm{Me}_{2} \mathrm{C}_{6} \mathrm{H}_{3}\right)$, which slowly polymerizes NBE [16]. The $\left[\mathrm{W}_{2}\left(\mathrm{OCH}_{2}{ }^{t} \mathrm{Bu}\right)_{6}(\mathrm{py})_{2}\right]\left(\left(\mathrm{W}^{3}-\mathrm{W}\right)^{6+}, \sigma^{2} \pi^{4}\right)$ alkoxide has been reported for the ROMP of NBD, but no detailed data have been presented [17,18].

Current research is more and more directed towards the production of often synthetically very complex functional molecules, the properties of which sensitively depend on their microstructure (primary, secondary, tertiary). This, in effect, is directly related to the stereoselectivity of the reaction, but tuning the configuration of the polymers has been a long-standing problem [19]. A good degree of control of the primary structure (gradient of cis and trans $\mathrm{C}=\mathrm{C}$ bonds) can be achieved, either empirically, by using multicomponent systems (catalyst/co-catalyst/additives, such as Michael acceptors or chelating solvents acting as spectator ligands) [2] or by serendipity [20]. Alternatively, elaborate design (steric, electronic) catalysis is employed [19,21]. Mononuclear molybdenum halides (e.g., $\mathrm{MoCl}_{5}$ ) give predominantly trans-PNBE, whereas tungsten ones (e.g., $\mathrm{WCl}_{6}$ ) provide polymers having mixed conformations $[2,3]$. Industrially produced $\mathbf{P N B E}$ with the original $\mathrm{RuCl}_{3} \cdot \mathrm{xH}_{2} \mathrm{O} / \mathrm{alcohol}$ system is highly trans (>90\%) [22].

Recently, as part of our studies in exploiting the reactivity of multiply bonded clusters, we have discovered that the ditungsten halide $\mathrm{Na}\left[\mathrm{W}_{2}\left(\mu-\mathrm{Cl}_{3} \mathrm{Cl}_{4}(\mathrm{THF})_{2}\right] \cdot(\mathrm{THF})_{3}\left(\mathbf{1}\right.\right.$, $\left.\left(\mathrm{W}^{-} \stackrel{3}{-} \mathrm{W}\right)^{6+}\right)$, a simple derivative of the historic $\left[\mathrm{W}_{2}(\mu-\mathrm{Cl})_{3} \mathrm{Cl}_{6}\right]^{3-}$ anion, discovered a century ago (1911) [23] and long considered a kinetic and thermodynamic sink in terms of its redox activity, catalyzes efficiently the metathetical polymerization of monosubstituted alkynes [24]. An interesting aspect of this initiator is its marked predilection to produce highly cis-polyacetylenes, which is unusual within the mononuclear tungsten halide analogs.

In this respect, and in view of: (a) the continuing interest on classical-type catalysts in industrial processes for highly active substrates, which may not justify the use of well-defined initiators [1-7,22], and (b) the importance of metal oxidation state in the search for new metathesis catalysts [12], as well as general comparison reasons (W(VI), $\mathrm{W}_{2}{ }^{6+}$ halides), we have extended our investigations into the reactions of 1 with NBE and some selected derivatives (5- $X$-2-NBE; $X=\mathrm{COOH}$ (NBE-COOH), OH (NBE-OH), $\mathrm{CN}$ (NBE-CN), COOMe (NBE-COOMe), $\mathrm{CH}=\mathrm{CH}_{2}$ (VNBE); norbornadiene (NBD)). 
Herein, we report its ability to efficiently induce the ROMP of most of these substrates with a high degree of stereoselectivity. The results are summarized in Table 1. Characterization of the polymers formed and mechanistic aspects of these reactions are also presented.

\section{Experimental Section}

\subsection{General}

Starting materials were purchased from Sigma-Aldrich and are of the highest available purities. Complexes $\mathrm{Na}\left[\mathrm{W}_{2}(\mu-\mathrm{Cl})_{3} \mathrm{Cl}_{4}(\mathrm{THF})_{2}\right] \cdot(\mathrm{THF})_{3} \quad$ (1) $\quad[25], \quad\left({ }^{n} \mathrm{Bu}_{4} \mathrm{~N}\right)_{3}\left[\mathrm{~W}_{2}\left(\mu-\mathrm{Cl}_{3} \mathrm{Cl}_{6}\right] \quad\right.$ (2) [26] and $\left({ }^{n} \mathrm{Bu}_{4} \mathrm{~N}\right)\left[\mathrm{W}_{2}(\mu-\mathrm{Cl})_{3} \mathrm{Cl}_{5}\right.$ (THF)] (3) [27] were prepared according to literature procedures. NBE was dissolved in the solvent used in the reaction, dried by stirring with $\mathrm{CaH}_{2}$ under argon and was distilled under vacuum prior to use. NBD was passed through an $\mathrm{Al}_{2} \mathrm{O}_{3}$ column. THF and diethyl ether were distilled over $\mathrm{Na} / \mathrm{Ph}_{2} \mathrm{CO}$, toluene and hexane over $\mathrm{Na}, \mathrm{CH}_{2} \mathrm{Cl}_{2}$ over $\mathrm{CaH}_{2}$, and methanol over sodium methoxide. Benzaldehyde was purified by distillation under reduced pressure. All solvents were distilled in an inert atmosphere, and were degassed by three freeze-pump-thaw cycles, with the exception of methanol, which was degassed by bubbling nitrogen or argon for $0.5 \mathrm{~h}$. All operations were performed under a pure dinitrogen or argon atmosphere, using Schlenk techniques on an inert gas/vacuum manifold or in a drybox $\left(\mathrm{O}_{2}, \mathrm{H}_{2} \mathrm{O}<1 \mathrm{ppm}\right)$.

NMR spectra were recorded on a Varian Unity Plus 300 spectrometer. In all cases, chemical shifts are reported in ppm relative to the deuterated solvent resonances. Size exclusion chromatography (SEC) experiments were carried out with a modular instrument consisting of a Waters model 600 pump, a Waters model U6K sample injector, a Waters model 410 differential refractometer and a set of $4 \mu$-Styragel columns with a continuous porosity range of $10^{6}-10^{3} \AA$. The columns were housed in an oven thermostated at $40{ }^{\circ} \mathrm{C}$. THF was the carrier solvent at a flow rate of $1 \mathrm{~mL} / \mathrm{min}$. The instrument was calibrated with PS standards covering the molecular weight range of 4000-900,000.

\subsection{Catalytic Reactions}

A typical procedure is described as follows. The substrate (e.g., NBE, $423 \mathrm{mg}, 4.5 \mathrm{mmol}$ ) was added to a solution of complex (e.g., 1:9.0 $\mathrm{mg}, 0.009 \mathrm{mmol})$ in a solvent $(2.0 \mathrm{~mL})$. The mixture was allowed to react for a given time (see Table 1), after which it was concentrated to half volume and treated with excess methanol to precipitate the polymeric products. The resulting solids were filtered and washed repeatedly with methanol. They were redissolved in THF and the above procedure was repeated. The products were dried in vacuo.

\subsection{Catalytic Reactions in NMR Tubes}

Complex 1 was dissolved in THF- $d^{8}(8.0 \mathrm{mg}, 0.008 \mathrm{mmol})$ and the green solution was transferred in an NMR tube. The appropriate amount of the substrate (NBD: $15.1 \mathrm{mg}, 16 \mu \mathrm{L}, 0.16 \mathrm{mmol}$; NBE: $150.6 \mathrm{mg}, 1.60 \mathrm{mmol})$ was added using a microliter syringe. 


\subsection{Polymer Microstructure}

The stereochemistry of the polymers obtained (PNBE, PNBE-COOME, PVNBE and the soluble part of PNBD) was determined by ${ }^{1} \mathrm{H}$ and ${ }^{13} \mathrm{C}$ NMR [28-32].

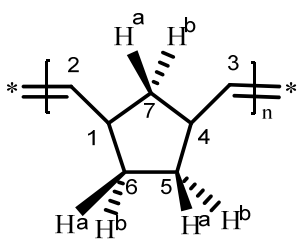

PNBE

${ }^{1} \mathrm{H} \mathrm{NMR}\left(\mathrm{CCl}_{4}, 300 \mathrm{MHz}\right): 5.25$ (s, 2H, H $\mathrm{H}^{2,3}$ trans), $5.10\left(\mathrm{~s}, 2 \mathrm{H}, \mathrm{H}^{2,3}\right.$ cis $)$, 2.73 (broad, s, 2H, $\mathrm{H}^{1,4}$ cis), 2.37 (broad, $\mathrm{s}, 2 \mathrm{H}, \mathrm{H}^{1,4}$ trans), 1.95-1.60 (broad, $\mathrm{m}, 3 \mathrm{H}, \mathrm{H}^{5 \mathrm{a}, 6 \mathrm{a}, 7 \mathrm{a}}$ ), 1.50-1.20 (broad, $\mathrm{m}, 2 \mathrm{H}, \mathrm{H}^{5 \mathrm{~b}, 6 \mathrm{~b}}$ ), 1.20-0.85 ppm (broad, m, $\left.1 \mathrm{H}, \mathrm{H}^{7 \mathrm{~b}}\right) ;{ }^{13} \mathrm{C} \mathrm{NMR}\left(\mathrm{CCl}_{4}, 75.4 \mathrm{MHz}\right): 133.99\left(\mathrm{~s}, \mathrm{C}^{2,3} c c c\right), 133.21(\mathrm{~m}$, $\left.\mathrm{C}^{2,3} \mathrm{ctt} / \mathrm{ttt} / \mathrm{ctc}\right), 133.08\left(\mathrm{~s}, \mathrm{C}^{2,3} \mathrm{ttc}\right), 43.67\left(\mathrm{~s}, \mathrm{C}^{1,4} \mathrm{tc}\right), 43.44\left(\mathrm{~s}, \mathrm{C}^{1,4} \mathrm{tt}\right), 42.88(\mathrm{~s}$, $\left.\mathrm{C}^{7} c c\right), 42.25\left(\mathrm{~s}, \mathrm{C}^{7} c t / t c\right), 41.52\left(\mathrm{~s}, \mathrm{C}^{7} t t\right), 38.88\left(\mathrm{~s}, \mathrm{C}^{1,4} c c\right), 38.67\left(\mathrm{~s}, \mathrm{C}^{1,4} c t\right)$, $33.39\left(\mathrm{~s}, \mathrm{C}^{5,6} c c\right), 33.19\left(\mathrm{~s}, \mathrm{C}^{5,6} c t\right), 32.61\left(\mathrm{~s}, \mathrm{C}^{5,6} t c\right), 32.43 \mathrm{ppm}\left(\mathrm{s}, \mathrm{C}^{5,6} t t\right)$.

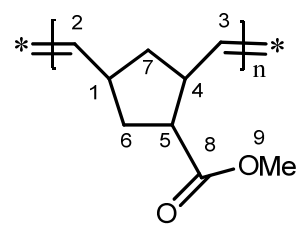

PNBE-COOME

${ }^{1} \mathrm{H}$ NMR $\left(\mathrm{CCl}_{4}, 300 \mathrm{MHz}\right.$ ): 5.26-5.37 (broad, 2H, H${ }^{2,3}$ ), 2.76-3.10 (broad, s, $1 \mathrm{H}, \mathrm{H}^{4}$ ), 2.26 (broad, s, 1H, $\mathrm{H}^{5}$ ), 1.80-2.10 (broad, m, 3H, $\mathrm{H}^{9}$ ), 1.10-1.60 (broad, $\left.\mathrm{m}, 3 \mathrm{H}, \mathrm{H}^{1,6,7}\right) ;{ }^{13} \mathrm{C} \mathrm{NMR}\left(\mathrm{CCl}_{4}, 75.4 \mathrm{MHz}\right): 170.7\left(\mathrm{~s}, \mathrm{C}^{8}\right)$, 140.9-127.4 (m, $\left.\mathrm{C}^{2,3}\right), 51.1\left(\mathrm{~s}, \mathrm{C}^{9}\right), 48.6-34.8 \mathrm{ppm}\left(\mathrm{s}, \mathrm{C}^{1,4,5,6,7}\right)$.

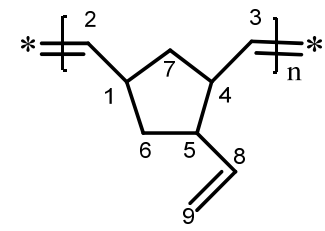

${ }^{1} \mathrm{H}$ NMR $\left(\mathrm{CCl}_{4}, 300 \mathrm{MHz}\right): 5.76\left(\right.$ broad, $\left.1 \mathrm{H}, \mathrm{H}^{8}\right), 5.30\left(\right.$ broad, $\left.2 \mathrm{H}, \mathrm{H}^{2,3}\right)$, 4.89-4.96 (broad, 2H, $\mathrm{H}^{9}$ ), 2.19-3.10 (broad, 3H, $\mathrm{H}^{1,4,5}$ ), 1.10-2.10 (broad, m, $\left.2 \mathrm{H}, \mathrm{H}^{6,7}\right) ;{ }^{13} \mathrm{C} \mathrm{NMR}\left(\mathrm{CCl}_{4}, 75.4 \mathrm{MHz}\right): 141.7,140.6\left(\mathrm{~s}, \mathrm{C}^{8}\right), 135.6-130.3(\mathrm{~m}$, $\left.\mathrm{C}^{2,3}\right), 113.6,113.1\left(\mathrm{~s}, \mathrm{C}^{9}\right), 50.1,47.9\left(\mathrm{~s}, \mathrm{C}^{5}\right), 45.6,37.5\left(\mathrm{~s}, \mathrm{C}^{1}\right), 45.6,41.3(\mathrm{~s}$, PVNBE $\left.\mathrm{C}^{4}\right), 42.8,41.3,39.5\left(\mathrm{~s}, \mathrm{C}^{7}\right), 41.3\left(\mathrm{~s}, \mathrm{C}^{6}\right)$.

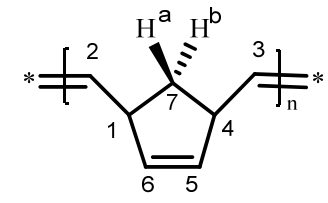

PNBD

${ }^{1} \mathrm{H}$ NMR $\left(\mathrm{CDCl}_{3}, 300 \mathrm{MHz}\right): 5.65$ (s, 2H, $\mathrm{H}^{5,6}$ trans), 5.60 (s, 2H, $\mathrm{H}^{5,6}$ cis), $5.40\left(\mathrm{~m}, 2 \mathrm{H}, \mathrm{H}^{2,3}\right.$ trans $), 5.25\left(\mathrm{~m}, 2 \mathrm{H}, \mathrm{H}^{2,3}\right.$ cis $), 3.60\left(\mathrm{~m}, 2 \mathrm{H}, \mathrm{H}^{1,4}\right.$ cis $)$, $3.20\left(\mathrm{~m}, 2 \mathrm{H}, \mathrm{H}^{1,4}\right.$ trans $), 2.40\left(\mathrm{~m}, 1 \mathrm{H}, \mathrm{H}_{7}\right), 1.27 \mathrm{ppm}\left(\mathrm{m}, 1 \mathrm{H}, \mathrm{H}_{7}\right) ;{ }^{13} \mathrm{C} \mathrm{NMR}$ $\left(\mathrm{CDCl}_{3}, 75.4 \mathrm{MHz}\right): 134.96\left(\mathrm{~s}, \mathrm{C}^{5,6} c c\right), 134.88\left(\mathrm{~s}, \mathrm{C}^{5,6} t t\right), 133.50\left(\mathrm{~s}, \mathrm{C}^{2,3} c t\right)$, $133.37\left(\mathrm{~s}, \mathrm{C}^{2,3} c c\right), 133.20\left(\mathrm{~s}, \mathrm{C}^{2,3} t t\right), 133.10\left(\mathrm{~s}, \mathrm{C}^{2,3} t c\right), 48.64\left(\mathrm{~s}, \mathrm{C}^{1,4} t c\right)$, $48.58\left(\mathrm{~s}, \mathrm{C}^{1,4} t t\right), 43.95\left(\mathrm{~s}, \mathrm{C}^{1,4} c c\right), 43.89\left(\mathrm{~s}, \mathrm{C}^{1,4} c t\right), 39.85\left(\mathrm{~s}, \mathrm{C}^{7} c c\right), 39.34$ (s, $\left.\mathrm{C}^{7} t c / c t\right), 38.80 \mathrm{ppm}\left(\mathrm{s}, \mathrm{C}^{7} t t\right)$.

\section{Results and Discussion}

\subsection{Catalyst and Polymerization Reactions}

Complex 1 has been isolated and structurally characterized [25]. In the solid state it contains a tungsten-tungsten triple bond, bearing three halide bridges and two THF ligands, one in each tungsten atom, in a cis arrangement along the dimetal axis. Such species in solution, in the presence of donor ligands or coordinating solvents, may exist in an equilibrium between the highly symmetric confacial ( $D_{3 \mathrm{~h}}$, fasbo) structure 1 and the edge-sharing $\left(\mathrm{D}_{2 \mathrm{~h}}\right.$, esbo) biooctahedral one $\mathbf{1}^{\prime}$ (Scheme $\mathrm{S} 1$ in the Supporting Information) [33]. It is air sensitive (oxygen, moisture), but in the solid state, it is stable at room temperature for a few hours. It is soluble in THF, $\mathrm{CH}_{3} \mathrm{CN}$ and dme, less soluble in $\mathrm{CH}_{2} \mathrm{Cl}_{2}$, and 
insoluble in toluene, $\mathrm{Et}_{2} \mathrm{O}$ and $\mathrm{CS}_{2}$. The complex has been repeatedly recrystallized and checked carefully for purity (Vis-UV) before use. Polymerization reactions were carried out at room temperature, for a given time. The results are summarized in Table 1.

\subsection{Polymerization of $\mathbf{N B E}$ and Derivatives}

The polymerization reactions of NBE were carried out in different media and were found to be solvent dependent. They do not proceed in strongly coordinating or chelating solvents $\left(\mathrm{CH}_{3} \mathrm{CN}\right.$, dimethoxyethane (dme)), indicating the inhibition of substrate coordination. They are slow in THF affording small yields (entry 1), while in $\mathrm{CH}_{2} \mathrm{Cl}_{2}$ fast gelation is observed and the polymer has low polydispersity index $\left(M_{\mathrm{w}} / M_{\mathrm{n}}\right.$, entry 2$)$. Suspension of $\mathbf{1}$ in toluene gives moderate yield of PNBE (entry 5), while suspensions in $\mathrm{Et}_{2} \mathrm{O}$ and $\mathrm{CS}_{2}$ (entries 6 and 7) give high yields of the polymer. After the end of the heterogeneous reactions, the catalyst can be separated and reused (at least four times) with fresh amounts of monomer and solvent, without significant loss of reactivity. The supernatant solution remains colorless during the reaction. The cis-stereoselectivity is high $(80 \%-86 \%)$ and is not affected by the reaction conditions.

All polymers are soluble in common organic solvents $\left(\mathrm{CHCl}_{3}, \mathrm{CH}_{2} \mathrm{Cl}_{2}, \mathrm{THF}\right)$. Their geometric structure was determined by ${ }^{1} \mathrm{H}$ and ${ }^{13} \mathrm{C}$ NMR spectra (Figure S1) [28]. The relative proportions of double-bond pair sequences, represented as trans-cis (tc), trans-trans (tt), cis-cis (cc) and cis-trans (ct) units, were determined from the four methine carbon $\left(\mathrm{C}^{1,4}\right)$ signals of the ${ }^{13} \mathrm{C}$ NMR spectrum of PNBE at $\delta_{\mathrm{C}} 43.67(t c), 43.44(t t), 38.88(c c)$ and $38.67 \mathrm{ppm}(c t)$. The fraction of $c i s$ double bonds $\left(\sigma_{\mathrm{c}}=0.85\right)$ estimated from this ${ }^{13} \mathrm{C}$ NMR spectrum is in good agreement with that obtained from the ${ }^{1} \mathrm{H}$ NMR spectrum $\left(\sigma_{\mathrm{c}}=0.86\right.$ from the integrals of the signals at $\delta_{\mathrm{H}} 2.73\left(\mathrm{HC}^{1,4}\right.$ cis-PNBE) and $2.37 \mathrm{ppm}\left(\mathrm{HC}^{1,4}\right.$ trans-PNBE). The reactivity ratios $r_{c}=c c / c t=7.4, r_{t}=t t / t c=1.3$ and $r_{c} r_{t}=9.6$ were calculated from the heights of the relevant signals in the ${ }^{13} \mathrm{C}$ NMR spectra.

Comparison of 1 (as per reactivity, yield, $M_{\mathrm{w}}$, and cis-selectivity) with other representative catalytic systems revealed that it is much more reactive than the Masuda type W(VI) halides, resembling more to the bicomponent ones (e.g., $\mathrm{WCl}_{6} / \mathrm{AlEtCl}_{2}, \mathrm{SnMe}_{4}$ etc.) and to the high-valent well-defined Schrock carbenes. Its cis-specificity is much more enhanced than that of the aforementioned systems, but it is comparable to that of the low-valent (Katz) and high-valent design catalysts (Schrock, Basset).

Substrates having strongly coordinating substituent groups $(-\mathrm{COOH},-\mathrm{OH},-\mathrm{CN})$ deactivate 1, while those with softer ones $\left(-\mathrm{COOMe},-\mathrm{CH}=\mathrm{CH}_{2}\right)$ are quantitatively polymerized, albeit with lower rates than NBE (Table 1, entries 11 and 12). The polymers are white, elastomeric, soluble in organic solvents and they have been characterized from their ${ }^{1} \mathrm{H}$ and ${ }^{13} \mathrm{C}$ NMR spectra. The broadness of the peak of olefinic protons (5.26-5.37 ppm) of NBE-COOMe (because of overlapping signals of endo-, exo-isomers, possibly presence of $\mathrm{HH}, \mathrm{HT}$ and TT units) and the complexity of the ${ }^{13} \mathrm{C}$ NMR spectra prevents the estimation of the cis-content $[29,30]$. In the case of PVNBE, the peak at $5.30 \mathrm{ppm}$ suggests that the ring-strained $\mathrm{C}=\mathrm{C}$ bond is cleaved, while the vinylic one is left intact. The overlapping signals of the olefinic protons of the polymeric chain with the vinylic ones prevent the stereoregular assignment for the same reasons as above [30]. NBE-COOMe has been polymerized by a variety of catalytic systems (Mo, W, Re, Ru, Os, Ir) with yields varying from $20 \%$ to quantitative and molecular weights higher than 800,000 [29]. In contrast, there is only one report for the polymerization 
of VNBE, namely with the $\left[(\mathrm{OC})_{4} \mathrm{~W}(\mu-\mathrm{Cl})_{3} \mathrm{~W}\left(\mathrm{GeCl}_{3}\right)(\mathrm{CO})_{3}\right](4)$ complex under controlled conditions, giving high yields of PVNBE along with small amounts of side products ( $10 \%)$ [31]. Both of these monomers are of interest, as their polymers can be easily functionalized by the addition of new side groups.

Finally, it must be noted that the isostructural and isoelectronic perhalocomplex $\left({ }^{n} \mathrm{Bu}_{4} \mathrm{~N}\right)_{3}\left[\mathrm{~W}_{2}(\mu-\mathrm{Cl})_{3} \mathrm{Cl}_{6}\right]$ (2) [26] under the same conditions was found inactive towards the ROMP of NBE, whereas the monosubstituted $\mathrm{W}_{2}{ }^{7+}$ derivative $\left({ }^{n} \mathrm{Bu}_{4} \mathrm{~N}\right)\left[\mathrm{W}_{2}(\mu-\mathrm{Cl})_{3} \mathrm{Cl}_{5}(\mathrm{THF})\right]$ (3) [27] provided very small yield $(\sim 10 \%)$.

\subsection{Polymerization of NBD}

The reactions of NBD with 1 homogeneously or heterogeneously (bulk or suspension in toluene) occur very fast and in quantitative yields (Table 1, entries 13-16). In a solvent-free regime, the polymer can be detached from the surface of the catalyst, which can be reused for several times. The PNBD formed is insoluble in most common organic solvents, indicating extensive cross-linking of the cyclopentene rings. At lower concentrations (1/NBD: 1/20) a partly soluble polymer $\left(\mathrm{CHCl}_{3}\right)$ is obtained. The microstructure of the soluble PNBD has been analyzed [32] (Figure S2). From the integral ratio of signal due to olefinic protons $\delta_{\mathrm{H}}=5.40$ (trans double bond) and $\delta_{\mathrm{H}}=5.60 \mathrm{ppm}$ (cis double bond), the value of the cis double bond content was calculated to be $c a$. $63 \%$. A cis double bond content of $c a$. $68 \%$ was calculated from the ${ }^{13} \mathrm{C}$ NMR spectrum. For this purpose, the well-resolved peaks of the methine carbon $\left(\mathrm{C}^{1,4}\right)$ at $\delta_{C} 48.58$ (trans double bond) and $43.95 \mathrm{ppm}$ (cis double bond) were integrated.

Table 1. Reactions of 1 with bicycloolefins ${ }^{a}$.

\begin{tabular}{|c|c|c|c|c|c|c|c|}
\hline Entry & Monomer & Solvent & $t(h)$ & Yield (\%) & $M_{\mathrm{w}} \times 10^{-3 \mathrm{~b}}$ & $M_{\mathrm{w}} / M_{\mathrm{n}}$ & $\operatorname{cis}(\%)$ \\
\hline 1 & \multirow{7}{*}{ NBE } & THF & 19 & 12 & 86.2 & 1.2 & 86 \\
\hline 2 & & $\mathrm{CH}_{2} \mathrm{Cl}_{2}$ & 1 & 96 & 529 & 1.2 & 86 \\
\hline 3 & & dme & 48 & $-{ }^{c}$ & - & - & - \\
\hline 4 & & $\mathrm{CH}_{3} \mathrm{CN}$ & 48 & $-{ }^{c}$ & - & - & - \\
\hline 5 & & toluene & 24 & 37 & 296 & 2.9 & 86 \\
\hline 6 & & $\mathrm{Et}_{2} \mathrm{O}$ & 20 & 94 & 422 & 1.4 & 86 \\
\hline 7 & & $\mathrm{CS}_{2}$ & 24 & 93 & 1,174 & 1.4 & 80 \\
\hline 8 & NBE-COOH & $\mathrm{CH}_{2} \mathrm{Cl}_{2}$ & - & $-{ }^{\mathrm{c}}$ & - & - & - \\
\hline 9 & NBE-OH & $\mathrm{CH}_{2} \mathrm{Cl}_{2}$ & - & $-{ }^{\mathrm{c}}$ & - & - & - \\
\hline 10 & NBE-CN & $\mathrm{CH}_{2} \mathrm{Cl}_{2}$ & - & $-^{\mathrm{c}}$ & - & - & - \\
\hline 11 & NBE-COOMe & $\mathrm{CH}_{2} \mathrm{Cl}_{2}$ & 12 & $>99$ & 685 & 1.15 & - \\
\hline 12 & VNBE & $\mathrm{CH}_{2} \mathrm{Cl}_{2}$ & 8 & $>99$ & 974 & 2.6 & - \\
\hline 13 & \multirow{4}{*}{ NBD } & - & 0.1 & $>99$ & - & - & - \\
\hline 14 & & THF & 4 & $>99$ & - & - & - \\
\hline 15 & & toluene & 0.1 & $>99$ & - & - & - \\
\hline 16 & & $\mathrm{CH}_{2} \mathrm{Cl}_{2}$ & 0.1 & $>99$ & - & - & - \\
\hline
\end{tabular}

${ }^{\mathrm{a}}$ Conditions: 1 (9.0 mg, $\left.0.009 \mathrm{mmol}\right)$, monomer $(4.5 \mathrm{mmol}) / 2.0 \mathrm{~mL}$ solvent; ${ }^{\mathrm{b}} \mathrm{By} \mathrm{SEC}$ in $\mathrm{THF}$ at $40{ }^{\circ} \mathrm{C}$;

${ }^{\mathrm{c}}$ No polymerization. 


\subsection{Mechanistic Considerations}

Mechanistically, the metal-olefin transformation to active carbenes or metallocyclobutanes in "ill-defined" catalytic systems is an intriguing problem, and several mechanistic pathways concerning mostly mononuclear complexes have been proposed [2,3,34-40]. In the simple case of NBE, the rearrangement is believed to be a net 1,2-H-shift along the metal coordinated $\mathrm{C}=\mathrm{C}$ bond, based on experimental evidence [36-40,41]. The higher unsaturation of NBD makes its transformations far more complicated than it had been considered and remain elusive.

In relation to this work, worth noting in some detail are the results reported by Szymańska-Buzar et al. on the mechanism of ROMP of NBE and NBD with a series of heterobimetallic M-M' $(\mathrm{M}=\mathrm{Mo}, \mathrm{W}$; $\left.\mathrm{M}^{\prime}=\mathrm{Sn}, \mathrm{Ge}\right)$ complexes, e.g., $\left[\mathrm{MCl}(\mathrm{SnCl})_{3}(\mathrm{CO})_{3}(\mathrm{NCMe})_{2}\right]\left(\mathbf{5}, \mathrm{M}=\mathrm{W} ; \mathbf{5}^{\prime}, \mathrm{M}=\mathrm{Mo}\right)$ and $\left[(\mathrm{OC})_{4} \mathrm{Mo}(\mu-\mathrm{Cl})_{3} \mathrm{Mo}\left(\mathrm{SnCl}_{3}\right)(\mathrm{CO})_{3}\right]$ (6) [35]. In the case of $\mathbf{5} / \mathbf{N B D}$, the first step of the reaction has been unequivocally established with the isolation and characterization (spectroscopic, structural) of the $\left[\mathrm{WCl}\left(\mathrm{SnCl}_{3}\right)(\mathrm{CO})_{3}\left(\eta^{4}-\mathbf{N B D}\right)\right]$ (5a) adduct, in which the two $\mathrm{C}=\mathrm{C}$ bonds of the NBD ligand are nonequivalently bonded to the tungsten atom. This compound has also been proven to be an efficient precatalyst for the ROMP of NBD, along with formation of minor amounts of exo-2-chloronorborn-5-ene and exo-3-chloronortricyclane [42]. Monitoring $\left({ }^{1} \mathrm{H}\right.$ and $\left.{ }^{13} \mathrm{C} \mathrm{NMR}\right)$ the reactions (5 or $\mathbf{5 a}$ in $\mathrm{CDCl}_{3}$ or $\mathrm{CDCl}_{3} / \mathrm{CD}_{2} \mathrm{Cl}_{2}$, room temperature) does not reveal the carbenic protons of the active species that trigger polymerization (attributed to their very small concentration). Exploratory density functional theory (DFT) calculations on the mechanism of the spontaneous $\eta^{4}$ NBD to carbene transformation have been carried out for complexes $\left[\mathrm{MoCl}\left(\mathrm{SnCl}_{3}\right)(\mathrm{CO})_{2}\left(\eta^{4}-\mathrm{NBD}\right)\right] \mathbf{5}^{\mathbf{2}} \mathbf{a}$ [42], $\left[\mathrm{MoCl}\left(\mathrm{SnCl}_{3}\right)(\mathrm{CO})_{2}(\mathrm{NCMe})_{2}\left(\eta^{4}-\mathrm{NBD}\right)\right]$ (7) [42], [W(CO) $\left.{ }_{3} \mathrm{I}_{2}\left(\eta^{4}-\mathrm{NBD}\right)\right]$ (8) [43] (forty pathways overall have been considered), but the activation energies were found too high. More recent calculations for $\left[\mathrm{W}(\mathrm{CO}) \mathrm{I}\left(\eta^{2}-\mathrm{dppm}\right)\left(\eta^{4}-\mathrm{NBD}\right)\right](9)$ taking into account extra important intermediate steps [44], which lower the activation energies by half, favor the mechanism first hypothesized by Handzlik et al. [42] (oxidative coupling to form metallacyclopentane, followed by a 1,4-H-shift between the two $\alpha$-bonded carbons across the face of the metal atom (Scheme S2).

In the case of NBE (4, 5a, 6), the corresponding $\eta^{2}$-NBE adducts are not isolable, but can be detected by ${ }^{1} \mathrm{H}$ NMR. Apart from polymer formation, exo-2-chloronorbornane and 2,2'-binorbornylidene (bi-NBE) were detected. The formation of bi-NBE provides direct evidence of $\eta^{2}$-NBE transformation to a tungstanorbornylidene species (1,2-hydride shift) capable to initiate either the ROMP of NBE, or a carbene-carbene coupling reaction, giving a new olefin (bi-NBE) [45-47].

The small initiation efficiency of $\mathbf{1}$ (it is calculated that only $\sim 10 \%$ of $\mathbf{1}$ is activated by NBE) coupled to the sensitivity of the active species, undermined our efforts to isolate adducts of 1 with NBD and NBE or any other catalytically active yield-related intermediates. Similar was the fate of attempts to establish whether the active species are bimetallic or $\mathbf{1}$ serves as a precursor to mononuclear compounds (by ESI-MS). Nevertheless, valuable information has been obtained by monitoring in situ the reactions of 1 with the substrates by ${ }^{1} \mathrm{H}$ and ${ }^{13} \mathrm{C}$ NMR. Solvent of choice was tetrahydrofuran (THF) because of the rapidity of the polymerizations in halogenated solvents $\left(\mathrm{CHCl}_{3}\right.$, $\mathrm{CH}_{2} \mathrm{Cl}_{2}$, PNBD formation even at low ratio (1/NBD: 1/2), gelation at higher ones) and the insufficient solubility of $\mathbf{1}$ in the above solvents at lower temperatures. 
In the case of NBD, as soon as it was added to a catalyst solution (1/NBD 1/20, THF- $d^{8}$; Figures S3 and S4) the peaks at 4.30 and $1.98 \mathrm{ppm}$, due to the coordinated THF molecules, instantly diminish and gradually disappear, indicating their fast displacement by the substrate, but no peaks due to adduct formation could be detected. Instead, at $t=0-1 \mathrm{~h}$, multiple broad unresolved high field peaks in the region 9.80-13.80 ppm, characteristic of the propagating tungsten alkylidene PNBD chains [2,48,49] appear simultaneously with peaks at $6.18,5.90,3.78$ and $2.92 \mathrm{ppm}$, and one at $3.92 \mathrm{ppm}$, which could be assigned to the formation of exo-2-chloronorborn-5-ene and exo-3-chloronortricyclane, respectively [42]. As the reaction progresses, the intensity of the above peaks increases, along with parallel and increasing formation of PNBD. Corroborative evidence for the alkylidene ligand(s) by ${ }^{13} \mathrm{C}-\mathrm{NMR}$ could not be obtained, presumably as a consequence of their minute concentration. The multiplicity of the signals could be attributed either to formation of several active species deriving from the 1/NBD interaction, to fasbo/esbo equilibria and/or concurrent metathetical reactions. Their broad unresolved nature may be due to paramagnetism of the active species [50], restricted rotation of the alkylidene ligand(s) and/or the existence of several species with nominally similar structural features and slightly differing environments, possibly isomeric alkylidene THF adducts of the type $\left\{\right.$ ' $\mathrm{W}_{x}$ " $\left.(=\mathrm{CHP})(\mathrm{THF})_{y}\right\} \quad(\mathrm{P}=$ polymer chain; $x, y=1$ or 2$)$. Quenching the reaction mixture with benzaldehyde (1/NBD/PhCHO: 1/20/100) causes the disappearance of the high-field peaks.

Interestingly, detection of the 1/NBD interaction has been possible at stoichiometric catalyst to substrate ratio (Figure S5). Under these conditions, ligand (THF) displacement is slower and accompanied with observation of small peaks at 5.44, 5.20 and $4.62 \mathrm{ppm}$ (ratio $\approx 2: 2: 1$ ) indicative of coordinated olefinic protons (absorptions are at higher field than those of free NBD by 1.28, 1.50 and $2.10 \mathrm{ppm}$, respectively). When substitution is nearly complete $(t=4 \mathrm{~h})$, the first two nearly disappear, while the third increases and becomes dominant. This peak may be assigned to the equivalently bound olefinic protons of an $\eta^{4}$-NBD ligand, either bridging the two tungsten atoms (1a) or chelating at one of them (1'a, Scheme 2). In support of formation of 1a is the considerable insight on alkyne activation at bimetallic metal-metal bonded Group 6 centers [33,51,52], and in this particular case, the formation of $\left[\mathrm{W}_{2}(\mu-\mathrm{Cl})_{3} \mathrm{Cl}_{4}\left(\eta^{2}-\mathrm{C}_{2} \mathrm{R}_{2}\right)_{2}\right]^{-}$and dimetallacarbotetrahedrane complexes $\left[\mathrm{W}_{2}(\mu-\mathrm{Cl})_{2} \mathrm{Cl}_{6}\left(\mu-\mathrm{C}_{2} \mathrm{R}_{2}\right)\right]^{2-}(\mathrm{R}$ $=\mathrm{Me}, \mathrm{Ph})$ deriving from the reaction of 1 with internal alkynes [53]; also, a limited number of representative alkene and diene interactions [54-60].

Evidently, our findings are remarkably similar to those reported by Szymańska-Buzar et al. on the polymerization of NBE and NBD by 5, 5' and 6 [35,42,45-47]. However, the NBD-to-carbene transformation in this system is more facile than those occurring in $\mathbf{5 a}$, and $\mathbf{6} / \mathbf{N B D}$, as this is reflected in the stabilities of the relevant adducts (4a stable and isolable; 1a or 1'a unstable) and the polymerization reaction rates, respectively (5 or $\mathbf{5 a} / \mathbf{N B D} / \mathrm{CHCl}_{3}$ or $\mathrm{CHCl}_{3} / \mathrm{CH}_{2} \mathrm{Cl}_{2}$ slow; $\mathbf{1} / \mathbf{N B D} / \mathrm{CH}_{2} \mathrm{Cl}_{2}$ vigorous).

At this stage, our understanding of the system does not allow for the drawing of solid conclusions. However, taking into account the results reported, those obtained in this work, as well as the characteristics of 1 (available coordination sites, $\mathrm{W}_{2}{ }^{6+}$ to $\mathrm{W}_{2}{ }^{8+}$ facile interconversions [26], favoring bimetallacycle formation [44], the synergistic effect of the $\mathrm{W}_{2}{ }^{6+}$ core that may substantially lower the required activation energies) [44,61], and providing that no other events during the reaction course induce rupture of 1 (e.g., disproportionation, excessive substrate binding), tentatively a bimetallic mechanism seems plausible and appears as a particularly attractive possibility (Scheme 2). 
Scheme 2. Schematic view of proposed bimetallic mechanism of polymerization of NBD with complex 1 .
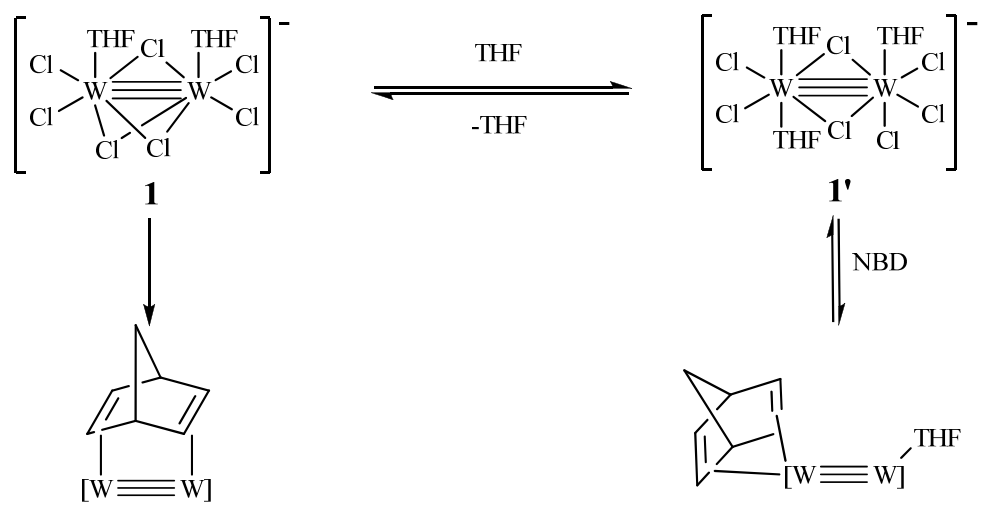

$1 \mathbf{a}$
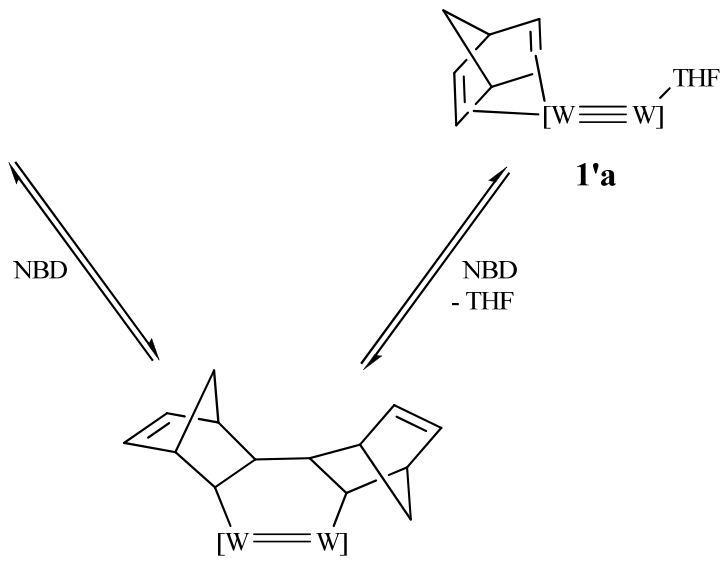

1b

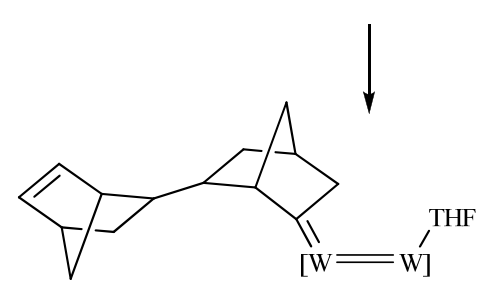

1c

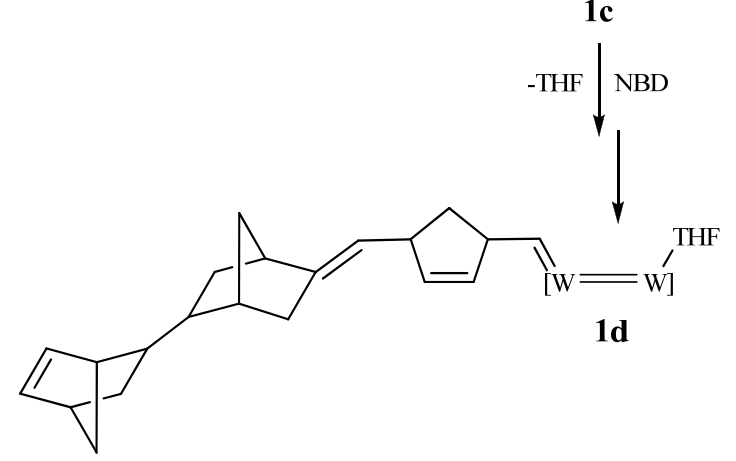

According to this scheme, there is no apparent reason that species $\mathbf{1 b} / \mathbf{1 c}$ should not retain their bimetallic integrity, since they would contain a tungsten-tungsten double bond of formal order of two $(\mathrm{W}=\mathrm{W})^{8+}$ supported by halide bridges. Such bridged $\mathrm{W}(\mathrm{IV})-\mathrm{W}(\mathrm{IV})$ double bonds are strong $\left(\left[\mathrm{W}_{2}(\mu-\mathrm{Cl})_{2} \mathrm{Cl}_{8}\right)\right]_{\mathrm{n}},(2.688(2) \AA)[62],\left[\mathrm{K}(18 \text {-crown-6) })_{1.5}\right]\left[\mathrm{W}_{2}(\mu-\mathrm{H})(\mu-\mathrm{O})\left(\mathrm{OC}^{t} \mathrm{Bu}\right)_{6}\right](2.445(1) \AA)$ [63], $\left.\left[\mathrm{W}_{2}\left(\kappa-\mathrm{O}_{2} \mathrm{C}^{t} \mathrm{Bu}\right)_{4}(\mu-\mathrm{MeCCMe})_{2}\right)\right](2.4888(2) \AA)$ [52], [ $\left.\left.\mathrm{W}_{2}\left(\kappa-\mathrm{O}_{2} \mathrm{C}^{t} \mathrm{Bu}\right)_{4}(\mu-\mathrm{PhCCMe})_{2}\right)\right](2.4925(2) \AA)$ [52], $\left[\mathrm{W}_{2}\left(\mathrm{OCH}_{2}{ }^{t} \mathrm{Bu}\right)_{8}\right]_{\mathrm{n}}[56]$. The $\mathbf{1 b} / \mathbf{1 c}$ transformation occurring by $a-\mathrm{H}$-abstraction induced by the vicinal tungsten atom, followed by ring opening ( $\mathrm{C}-\mathrm{H}$ bond formation), is a possibility worthy of further investigation. Subsequently, propagation may proceed further via a two-center "windscreen" mechanism. Such an hypothesis is not unprecedented and has been previously proposed to explain the 
ROMP of NBE along an edge of the trinuclear $\left[\mathrm{Os}_{3}(\mu-\mathrm{H})_{2}(\mathrm{CO})_{10}\right.$ ] cluster [64]. Alternatively, the possibility of 1c being bridging cannot be excluded; in such a case, the reaction may occur via a bimetallic mechanism, as encountered in alkyne and cycloolefin polymerization with the $\left[\mathrm{W}_{2}(\mathrm{CO})_{10}\left(\mu-\mathrm{CMe}_{2}\right)\right][65]$ and $\left[\mathrm{Cp}_{2} \mathrm{Ru}_{2}(\mathrm{CO})_{2}(\mu-\mathrm{CO})(\mu-\mathrm{CH}(\mathrm{Me})]\right.$ [66] bridging carbenes.

In the case of NBE, monitoring of the reactions, apart from the difficulties encountered in $\mathrm{CH}_{2} \mathrm{Cl}_{2}$, is hampered by additional ones, such as very slow reaction rates even at high $\mathbf{1} / \mathbf{N B E}(1 / 200)$ ratio and the masking of NBE and PNBE at the fingerprint regions of the ${ }^{1} \mathrm{H}$ NMR spectra, which makes results interpretation problematic. Competition between THF and substrate for ligation is evident, with the THF ligand displacement being very slow. Coordination of NBE could not be detected, but during the course of the reaction ( $t=0-20 \mathrm{~h}$ ) appearance of broad high-field peaks at the region 12.80-9.75 ppm (Figure S6), which may be assigned to the tungsten alkylidene PNBE propagating chains and of peaks at 3.84, 2.38, 2.30, 2.0-1.9 ppm (Figure S7), typical of exo-2-chloronorbornane [46,67], are observed. At longer times $(t=40 \mathrm{~h})$ the characteristic peaks of PNBE at 5.25 and 5.10 ppm appear, whereas the intensity of the alkylidenic proton signals decay, indicating their decomposition. In this case, the evidence concerning the first step(s) of the reaction and the mechanism overall is much less clear. The process may operate either by the coupling of two $\eta^{2}$-NBE ligands in a $\left[\mathrm{W}_{2} \mathrm{Cl}_{7}\left(\eta^{2}-\mathrm{NBE}\right)_{2}\right]^{-}$complex, in a manner analogous to that proposed for NBD, or with formation of a tungstenonorbornylidene species, deriving from the $\left[\mathrm{W}_{2} \mathrm{Cl}_{7}(\mathrm{THF})\left(\eta^{2}-\mathrm{NBE}\right)\right]^{-}$anion [45]. This bimetallic mechanism may also explain the high cis-efficiency of the reaction, in terms of an enhanced "wall type" [68] steric hindrance along the one side of the dimetal axis. This would oblige the incoming monomer molecule (NBE) to approach the metal center minimizing steric repulsions that is favorable for the formation of cis- rather than trans-junctions in the polymer chain. Such an effect has been considered responsible for the formation of an all-cis-PNBE polymer from the in situ reaction of $\mathrm{WCl}_{6} / \mathrm{PSLi} / \mathrm{NBE}$ (PS = polystyrene) [69] and the dramatic stereoselectivity changes of the $\left[\mathrm{Mo}_{2}(\mathrm{NCMe})_{8}\right]\left(\mathrm{BF}_{4}\right)_{4} / \mathrm{EtAlCl}_{2}$ $\left(\left(\mathrm{Mo}^{4} \mathrm{Mo}\right)^{4+}\right)$ system homogeneously $(30 \% \mathrm{cis})$ and heterogeneously $\left(\mathrm{SiO}_{2}, 70 \% \mathrm{cis}\right)[14]$.

\section{Conclusions}

From this work the following conclusions can be drawn:

(a) Complex $\mathbf{1}$ is an efficient homogeneous and/or heterogeneous unicomponent initiator for the ROMP of NBE, providing high molecular weight polymers in high yields and high stereoselectivity $(86 \%$ cis for PNBE). Strongly coordinating pendant groups $(-\mathrm{COOH},-\mathrm{OH}$, $-\mathrm{CN})$ deactivate 1 , softer ones do not affect its reactivity $(-\mathrm{COOMe})$, whereas less strained double bonds remain unaffected $\left(-\mathrm{CH}=\mathrm{CH}_{2}\right)$. NBD reacts fast and quantitatively giving insoluble polymers.

(b) The presence of two labile cis-THF ligands in $\mathbf{1}$ seems necessary for catalytic activity, as this derives from the inactivity of $\mathbf{2}$ or the very small activity of $\mathbf{3}$ under the same conditions.

(c) In situ monitoring of the reactions (1/NBD or NBE) by ${ }^{1} \mathrm{H}$ NMR allows the observation of the active alkylidenes of the propagating chains, but the in-depth mechanistic aspects of these reactions remain a cloudy landscape.

(d) The reactivity of $\mathbf{1}$ for the ROMP of NBE is higher than that of the classical mononuclear initiators and derivatives thereof, resembling more to the bi- or multicomponent ones (e.g., 
$\mathrm{WCl}_{6}$ /organometallic co-catalysts), and to the well-defined high-valent carbenes. Its cis-specificity is more enhanced than that of the above mentioned systems, and is comparable to that observed with the low-valent carbenes (Katz) and the high-valent stereoselective design catalysts (Schrock, Basset).

In summary, it could be said that the $\left[\mathrm{W}_{2} \mathrm{Cl}_{9}\right]^{3-}$ anion, which played an important role in the development of metal-metal multiple bonds and transition metal clusters, comes out of its hybernetic inertia and its simple derivative $\mathbf{1}$ emerges as an interesting precursor for metathesis reactions.

Future studies are planned in order to shed light on mechanism intricacies, and also to survey the reactivity of these initiators towards other ROMPable substrates, as well as in ROMP-related reactions.

\section{Acknowledgments}

This research has been co-financed by the European Union (European Social Fund-ESF) and Greek national funds through the Operational Program "Education and Lifelong Learning" of the National Strategic Reference Framework (NSRF) — Research Funding Program: THALIS — UOASynthesis of Novel Advanced Materials by New Generation Catalysts via Romp (Ring Opening Metathesis Polymerization) Reactions.

Financial support by the Special Account for Research Grants of the University of Athens is also acknowledged.

\section{References}

1. Ivin, K.J.; Mol, J.C. Olefin Metathesis and Metathesis Polymerization; Academic Press, Inc.: San Diego, CA, USA, 1997.

2. Dragutan, V.; Streck, R. Catalytic Polymerization of Cycloolefins. Ionic, Ziegler-Natta and Ring-Opening Metathesis Polymerization; Elsevier Science B.V.: Amsterdam, The Netherlands, 2000 .

3. Grubbs, R.H. Handbook of Metathesis; Wiley-VCH: Weinheim, Germany, 2003.

4. Frenzel, U.; Müller, B.K.M.; Nuyken, O. Handbook of Polymer Synthesis, 2nd ed.; Kricheldorf, H.R., Nuyken, O., Swift, G., Eds.; Marcel Dekker: New York, NY, USA, 2005.

5. Buchmeiser, M.R. Homogeneous metathesis polymerization by well-defined group VI and group VIII transition-metal alkylidenes: Fundamentals and applications in the preparation of advanced materials. Chem. Rev. 2000, 100, 1565-1604.

6. Buchmeiser, M.R. Ring-opening metathesis polymerization. In Synthesis of Polymers: New Structures and Methods, 1st ed.; Schlüter, A.D., Hawker, C.J., Sakamoto, J., Eds.; Wiley-VCH: Weinheim, Germany, 2012.

7. Mol, J.C. Industrial applications of olefin metathesis. J. Mol. Catal. A Chem. 2004, 213, 39-45.

8. Madan, R.; Srivastava, A.; Anand, R.C.; Varma, I.K. Polymers derived from bicylo[2.2.1]heptene and its derivatives. Prog. Polym. Sci. 1998, 23, 621-663.

9. Szymańska-Buzar, T. Structure and reactivity of tungsten(II) and molybdenum(II) compounds containing an M-M' bond. Coord. Chem. Rev. 2005, 249, 2195-2202. 
10. Yamaguchi, Y.; Fujita, A.; Suzuki, N.; Ito, T. Metathesis polymerization of norbornene and terminal acetylenes catalyzed by bis(acetonitrile) complexes of molybdenum and tungsten. $J$. Mol. Catal. A Chem. 2005, 240, 226-232.

11. Kozmer, V.A.; Poletayeva, I.A.; Yufa, T.L. Cycloolefin polymerization initiated by transition metal- $\pi$-allylic complexes. J. Polym. Sci. A 1972, 10, 251-258.

12. Katz, T.J. Olefin metatheses and related reactions initiated by carbene derivatives of metals in low-oxidation states. Angew. Chem. Int. Ed. 2005, 44, 3010-3019.

13. Schrock, R.R. Recent advances in high oxidation state Mo and W imido alkylidene chemistry. Chem. Rev. 2009, 109, 3211-3226.

14. Adams, R.D.; Cotton, F.A. Catalysis by Di- and Polynuclear Metal Cluster Complexes; Wiley VCH: New York, NY, USA, 1999.

15. Brumaghim, J.L.; Girolami, G.S. Ring-opening metathesis polymerization of norbornene by $\mathrm{Cp}_{2}{ }_{2} \mathrm{Os}_{2} \mathrm{Br}_{4}$ and related compounds. Organometallics 1999, 18, 1923-1938.

16. Schrock, R.R.; Lopez, L.P.H.; Hafer, J.; Singh, R.; Sinha, A.; Müller, P. Olefin metathesis reactions initiated by $d^{2}$ molybdenum or tungsten complexes. Organometallics 2005, 24, 5211-5213.

17. Barry, J.T.; Chisholm, M.H. Selective hydrogenations of dienes and olefins by $\left[\mathrm{W}_{2}\left(\mathrm{OCH}_{2} \mathrm{Bu}^{\mathrm{t}}\right)_{6}(\mathrm{py})_{2}\right]$. J. Chem. Soc. Chem. Commun. 1995, 1599-1600.

18. Chisholm, M.H. Ditungsten hexaalkoxides: Templates for organometallic chemistry and catalysis. J. Chem. Soc. Dalton Trans. 1996, 1781-1791.

19. Schrock, R.R. Synthesis of stereoregular ROMP polymers using molybdenum and tungsten imido alkylidene initiators. Dalton Trans. 2011, 40, 7484-7495.

20. van der Schaaf, P.A.; Abbenhuis, R.A.T.M.; van der Noort, W.P.A.; de Graaf, R.; Grove, D.M.; Smeets, W.J.J.; Spek, A.L.; van Koten, G. Tungsten(VI) phenylimido alkylidene complexes containing a monoanionic $\mathrm{O}, \mathrm{N}$-chelating ligand and their isolated precursor complexes: $\mathrm{X}$-ray structures of $\mathrm{W}\left(\mathrm{CH}_{2} \mathrm{SiMe}_{3}\right)_{3}(=\mathrm{NPh})\left[\mathrm{OCPh}_{2}(2-\mathrm{py})\right]$ and $\mathrm{W}\left(=\mathrm{CHSiMe}_{3}\right)\left(\mathrm{CH}_{2} \mathrm{SiMe}_{3}\right)(=\mathrm{NPh})\left[\mathrm{OCPh}_{2}(2-\mathrm{py})\right]$. Organometallics 1994, 13, 1433-1444.

21. Basset, J.-M.; Leconte, M.; Lefebvre, F.; Hamilton, J.G.; Rooney, J.J. Stereoselectivity in cyclic and acyclic metathesis reactions. Macromol. Chem. Phys. 1997, 198, 3499-3506.

22. Mutch A., Leconte M., Lefebvre F.; Basset J.-M. Effect of alcohols and epoxides on the rate of ROMP of norbornene by a ruthenium trichloride catalyst. J. Mol. Catal. A Chem. 1998, 133, 191-199.

23. Olsson, O. Über die reduktion der wolframsäure und die tieferen oxydationsstufen des wolframs. I. Ber. Deutsch. Chem. Ges. 1913, 46, 566-582.

24. Saragas, N.; Floros, G.; Paraskevopoulou, P.; Psaroudakis, N.; Koinis, S.; Pitsikalis, M.; Mertis, K. Polymerization of terminal alkynes with a triply bonded ditungsten halo-complex. J. Mol. Catal. A Chem. 2009, 303, 124-131.

25. Chisholm, M.H.; Eichhorn, B.W.; Folting, K.; Huffman, J.C.; Ontiveros, C.D.; Streib, W.E.; van der Sluys, W.G. Preparation and characterization of $\mathrm{NaW}_{2} \mathrm{Cl}_{7}(\mathrm{THF})_{5}$. A synthetically useful precursor for $\mathrm{X}_{3} \mathrm{~W} \equiv \mathrm{WX}_{3}$ compounds where $X=\mathrm{CH}_{2}-t-\mathrm{Bu}, \mathrm{NMe}_{2}$, and $\mathrm{O}-t$-Bu. Inorg. Chem. 1987, 26, 3182-3186. 
26. Paraskevopoulou, P.; Petalidou, E.; Panas, A.; Ioannou, M.; Koinis, S.; Psaroudakis, N.; Leventis, N.; Stavropoulos, P.; Mertis, K. Redox reactivity and comprehensive synthetic chemistry of the perchloroditungstate $\left[\mathrm{W}_{2}(\mu-\mathrm{Cl})_{3} \mathrm{Cl}_{6}\right]^{n-}(n=3,2,1)$ anions in organic media. Polyhedron 2008, 27, 2859-2866.

27. Bergs, D.J.; Chisholm, M.H.; Folting, K.; Huffman, J.C.; Stahl, K.A. Preparation and characterization of the heptachlorobis(tetrahydrofuran)ditungstate and octachloro(tetrahydrofuran)ditungstate anions: $\left[\mathrm{Ph}_{4} \mathrm{P}\right]\left[\mathrm{W}_{2} \mathrm{Cl}_{7}(\mathrm{THF})_{2}\right]$ and $\left[\mathrm{Ph}_{4} \mathrm{P}\right]\left[\mathrm{W}_{2} \mathrm{Cl}_{8}(\mathrm{THF})\right]$. Inorg. Chem. 1988, 27, 2950-1954.

28. Düz, B.; Elbistan, C.K.; Ece, A.; Sevin, F. Application of carbon arc-generated Mo- and W-based catalyst systems to the ROMP of norbornene. Appl. Organometal. Chem. 2009, 23, 359-364.

29. Bell, B.; Hamilton, J.G.; Law, E.E.; Rooney, J.J. A one-pot synthesis of comb polymers and hydrogels by the ring-opening metathesis polymerization reaction. Macromol. Rapid Commun. 1994, 15, 543-550.

30. Vogel, N.; Théato, P. Controlled synthesis of reactive polymeric architectures using 5-norbornene-2-carboxylic acid pentafluorophenyl ester. Macromol. Symp. 2007, 249-250, 383-391.

31. Gorski, M.; Szymańska-Buzar, T. Tungsten(II)-initiated ring-opening metathesis polymerization and other $\mathrm{C}-\mathrm{C}$ bond forming reactions of 5-vinyl-2-norbornene. J. Mol. Cat. A Chem. 2006, 257, 41-47.

32. Bell, B.; Hamilton, J.G.; Mackey, O.N.D.; Rooney, J.J. Microstructure of ring-opened polymers and copolymers of norbomadiene. J. Mol. Catal. 1992, 77, 61-73.

33. Cotton, F.A.; Walton, R.A. Multiple Bonds between Metal Atoms, 3rd ed.; Springer: New York, NY, USA, 2005.

34. Bencze, L.; Kraut-Vass, A.; Prókai, L. Mechanism of initiation of the metathesis of norbornene using $\mathrm{W}(\mathrm{CO})_{3} \mathrm{Cl}_{2}\left(\mathrm{AsPh}_{3}\right)_{2}$ as catalyst. J. Chem. Soc. Chem. Comm. 1985, 911-912.

35. Czeluśniak, I.; Szymańska-Buzar, T. Ring-opening metathesis polymerization of norbornene and norbornadiene by tungsten(II) and molybdenum(II) complexes. J. Mol. Catal. A Chem. 2002, 190, 131-143.

36. Bencze, L.; Szalai, G.; Overton, T.L. Investigation of the catalytic properties of the thermally activated dichloro-tetracarbonyl-tungsten in olefin metathesis reaction. Inorg. Chim. Acta 1997, $254,5-7$.

37. Bencze, L.; Biró, N.; Szabó-Ravasz, B.; Mihichuk, L. Chemical transformations of cis-W(CO $)_{4}\left(\mathrm{C}_{5} \mathrm{H}_{5} \mathrm{~N}\right)_{2}$ in the ring-opening metathesis polymerization of norbornene. Can. J. Chem. 2004, 82, 499-503.

38. Farona, M.F.; Tucker, R.L. Studies on the mechanism of olefin metathesis promoted by a heterogeneous catalyst. J. Mol. Catal. 1980, 8, 85-90.

39. Szymańska-Buzar, T.; Głowiak, T.; Czeluśniak, I. The initiation of ring-opening metathesis polymerisation of norbornadiene by seven-coordinate molybdenum(II) compounds. X-ray crystal structure of $\left[\mathrm{Mo}(\mu-\mathrm{Cl})\left(\mathrm{SnCl}_{3}\right)(\mathrm{CO})_{3}\left(\eta^{4}-\mathrm{NBD}\right)\right]$. J. Organomet. Chem. 2001, 640, 72-78.

40. Szymańska-Buzar, T.; Głowiak, T.; Czeluśniak, I. Reactivity of $\left[\mathrm{Mo}(\mu-\mathrm{Cl})\left(\mathrm{SnCl}_{3}\right)(\mathrm{CO})_{3}(\mathrm{NCMe})_{2}\right]$ towards norbornadiene. X-ray crystal structure of $\left[\mathrm{Mo}(\mu-\mathrm{Cl})\left(\mathrm{SnCl}_{3}\right)(\mathrm{CO})_{2}\left(\eta^{4}-\mathrm{C}_{7} \mathrm{H}_{8}\right)(\mathrm{NCMe})\right]$. Polyhedron 2002, 21, 2505-2513. 
41. Veige, A.S.; Wolczanski, P.T.; Lobkovsky, E.B. Dehydrogenation of $\left[\left\{(\operatorname{silox})_{3} \mathrm{Nb}\right\}_{2}(\eta-1,2\right.$; $\left.\left.\eta-5,6-\mathrm{C}_{8} \mathrm{H}_{8}\right)\right]\left(\right.$ silox $\left.=t \mathrm{Bu}_{3} \mathrm{SiO}\right)$ to $\left[\left\{(\operatorname{silox})_{3} \mathrm{Nb}\right\}_{2}\left(\eta-1,2 ; \eta-5,6-\mathrm{C}_{8} \mathrm{H}_{6}\right)\right]$ and its subsequent alkene-to-alkylidene rearrangement. Angew. Chem. Int. Ed. 2001, 40, 3629-3632.

42. Handzlik, J.; Stosur, M.; Kochel, A.; Szymańska-Buzar, T. Norbornadiene complexes of molybdenum(II) and their transformation to a catalyst for ring-opening metathesis polymerization: DFT calculations-X-ray crystal structure of a new norbornadiene complex $\left[\mathrm{MoCl}\left(\mathrm{GeCl}_{3}\right)(\mathrm{CO})_{3}\left(\eta^{4}\right.\right.$-nbd)]. Inorg. Chim. Acta 2008, 361, 502-512.

43. East, A.L.L.; Berner, G.M.; Morcom, A.D.; Mihichuk, L. M. Computational study of tungsten(II)-catalyzed rearrangements of norbornadiene. J. Chem. Theory Comput. 2008, 4, $1274-1282$.

44. Jayaraman, A.; Berner, G.M.; Mihichuk, L.M.; East, A.L.L. Tungsten(II)-catalyzed rearrangements of norbornadiene: effects of alternative complexation stages. J. Mol. Catal. A Chem. 2011, 351, 143-153.

45. Malinowska, A.; Czeluśniak, I.; Górski, M.; Szymańska-Buzar, T. A novel catalytic route to 2-bicyclo[2.2.1] hept-2-ylidenebicyclo[2.2.1]-heptane involving $\mathrm{C}-\mathrm{H}$ bond activation of bicyclo[2.2.1] hept-2-ene. J. Mol. Catal. A Chem. 2005, 226, 259-262.

46. Górski, M.; Kochel, A.; Szymańska-Buzar, T. Photochemical reaction of $\mathrm{W}(\mathrm{CO})_{6}$ with $\mathrm{GeCl}_{4}$ as a source of germyl and germylene compounds acting as initiators for ring-opening metathesis polymerization of norbornene. J. Organomet. Chem. 2006, 691, 3708-3714.

47. Malinowska, A.; Kochel, A.; Szymańska-Buzar, T. An anionic binuclear complex of tungsten(II), $\left[(\mu-\mathrm{Cl})_{3}\left\{\mathrm{~W}\left(\mathrm{SnCl}_{3}\right)(\mathrm{CO})_{3}\right\}_{2}\right]^{-}$, and its reactivity towards norbornene. J. Organomet. Chem. 2007, 692, 3994-3999.

48. Kress, J.; Osborn, J.A.; Greene, R.M.E.; Ivin, K.J.; Rooney, J.J. The detection of "living" propagating tungsten-carbene complexes in the ring-opening polymerization of bicycloalkenes. $J$. Chem. Soc. Chem. Commun. 1985, 874-876.

49. Percec, V.; Künzler, J. Monitoring the $\mathrm{WCI}_{6} /\left(\mathrm{CH}_{3}\right)_{4} \mathrm{Sn}$ initiated polymerization of substituted acetylenes by ${ }^{1}$ H-NMR spectroscopy. Polym. Bull. 1991, 25, 483-490.

50. Dzik, W.I.; Zhang, X.P.; de Bruin, B. Redox noninnocence of carbene ligands: Carbene radicals in (catalytic) C-C bond formation. Inorg. Chem. 2011, 50, 9896-9903.

51. Kerby, M.C.; Eichhorn, B.W.; Doviken, L.; Vollhardt, K.P.C. Activated molybdenum-molybdenum quadruple bonds. 2. First example of alkyne additions to metal-metal quadruple bonds. Inorg. Chem. 1991, 30, 156-158.

52. Byrnes, M.J.; Chisholm, M.H.; Gallucci, J.; Wilson, P.J. Alkyne adducts of ditungsten tetrapivalate: $\left[\mathrm{W}_{2}\left(\kappa^{2}-\mathrm{O}_{2} \mathrm{C}^{\mathrm{t}} \mathrm{Bu}\right)_{4}\left(\mu-\mathrm{RCCR}^{\prime}\right)_{2}\right]$, where $\mathrm{R}=\mathrm{R}^{\prime}=\mathrm{Me}, \mathrm{Et}, \mathrm{Ph}$ and $\mathrm{R}=\mathrm{Me}, \mathrm{R}^{\prime}=\mathrm{Ph}$. Organometallics 2002, 21, 2240-2247.

53. Bott, S.G.; Clark, D.L.; Green, M.L.H.; Mountford, P. Chloride-supported tungsten alkyne complexes. Synthesis, electronic and molecular structures of $\left[\mathrm{W}_{2} \mathrm{Cl}_{4}(\mu-\mathrm{Cl})_{2}\left(\mu-\mathrm{C}_{2} \mathrm{R}_{2}\right)(\text { thf })_{2}\right](\mathrm{R}=\mathrm{H}$ or $\mathrm{Me})$ and $\left[\mathrm{WCl}_{4}\left(\eta-\mathrm{C}_{2} \mathrm{Me}_{2}\right)(\mathrm{thf})\right](\mathrm{thf}=$ tetrahydrofuran). J. Chem. Soc. Dalton Trans. 1991, $471-481$. 
54. Chisholm, M.H.; Huffman, J.C.; Hampden-Smith, M.J. Metal alkoxides. Models for metal oxides. 15. Carbon-carbon and carbon-hydrogen bond activation in the reactions between ethylene and ditungsten hexaalkoxides: $\mathrm{W}_{2}\left(\mathrm{OCH}_{2}-t-\mathrm{Bu}\right)_{6}\left(\eta^{2}-\mathrm{C}_{2} \mathrm{H}_{4}\right)_{2}, \quad \mathrm{~W}_{2}(\mathrm{OR})_{6}\left(\mathrm{CH}_{2}\right)_{4}\left(\eta^{2}-\mathrm{C}_{2} \mathrm{H}_{4}\right)$, and $\mathrm{W}_{2}(\mathrm{OR})_{6}$ $\left(\mu-\mathrm{CCH}_{2} \mathrm{CH}_{2} \mathrm{CH}_{2}\right.$ ) (where $\mathrm{R}=\mathrm{CH}_{2}-t-\mathrm{Bu}, i-\mathrm{Pr}, c-\mathrm{C}_{5} \mathrm{H}_{9}$, and $\mathrm{c}-\mathrm{C}_{6} \mathrm{H}_{11}$ ). Preparations, properties, structures, and reaction mechanisms. J. Am. Chem. Soc. 1989, 111, 5284-5299.

55. Chisholm, M.H.; Streib, W.E.; Tiedtke, D.B.; Wu, D.-D. Organometallic chemistry of $\left[\mathrm{W}_{2}\left(\mathrm{OCH}_{2}{ }^{t} \mathrm{Bu}\right)_{8}\right](\mathrm{M}=\mathrm{M})$ : substrate uptake and activation at a tungsten-tungsten double bond. Chem. Eur. J. 1998, 4, 1470-1479.

56. Lopez, L.P.H.; Schrock, R.R.; Müller, P. Dimers that contain unbridged W(IV)/W(IV) double bonds. Organometallics 2006, 25, 1978-1986.

57. Barry, J.T.; Bollinger, J.C.; Chisholm, M.H.; Glasgow, K.C.; Huffman, J.C.; Lucas, E.A.; Lubkovsky, E.B.; Streib, W.E. Preparation and characterization of 1,3-butadiene and isoprene complexes, $\mathrm{W}_{2}\left(\mathrm{OCH}_{2}{ }^{\mathrm{H}} \mathrm{Bu}\right)_{6}($ diene)(py), and studies of the selective hydrogenation of 1,3-dienes. Organometallics 1999, 18, 2300-2308.

58. Chisholm, M.H.; Rankel, L.A.; Bailey, W.I., Jr.; Cotton, F.A.; Murillo, C.A. $\mu$-Allene-bis(cyclopentadieny1)tetracarbonyl-dimolybdenum; a bridging allene ligand. J. Am. Chem. Soc. 1977, 99, 1261-1262.

59. Bailey, W.I., Jr.; Chisholm, M.H.; Cotton, F.A.; Murillo, C.A.; Rankel, L.A. Reactions of metal-to-metal multiple bonds. 1. $\mu$-Allene-bis(cyclopentadienyl)tetracarbonyldimolybdenum and -ditungsten compounds. Preparation, properties, and structural characterization. J. Am. Chem. Soc. 1978, 100, 802-807.

60. Cayton, R.H.; Chisholm, M.H.; Hampden-Smith, M.J. An allene adduct of ditungsten hexa-tert-butoxide: prediction of a stabilized $\mu-\eta^{3}-\mathrm{CH}_{2} \mathrm{CCH}_{2}$ moiety. J. Am. Chem. Soc. 1988, 110, 4438-4440.

61. Crabtree, R.H. The Organometallic Chemistry of the Transition Metals, 4th ed.; John Wiley \& Sons, Inc.: Hoboken, NJ, USA, 2005.

62. Kolesnichenko, V.; Swenson, D.C.; Messerle, L. Facile reduction of tungsten halides with nonconventional, mild reductants. I. Tungsten tetrachloride: several convenient solid-state syntheses, a solution synthesis of highly reactive $\left(\mathrm{WCl}_{4}\right)_{x}$, and the molecular structure of polymeric tungsten tetrachloride. Inorg. Chem. 1998, 37, 3257-3262.

63. Budzichowski, T.A.; Chisholm, M.H.; Folting, K.; Huffman, J.C.; Streib, W.E. Dimetal hepta- and octaalkoxide anions of molybdenum and tungsten, $\mathrm{M}_{2}(\mathrm{OR})_{7}{ }^{-}$and $\mathrm{M}_{2}(\mathrm{OR})_{8}{ }^{2-}(\mathrm{M} \equiv \mathrm{M})$. Preparation, structures, oxidation, and a study of the thermal decomposition of $\mathrm{M}_{2}(\mathrm{OR})_{7}{ }^{-}$to give $\mathrm{W}_{2}(\mathrm{H})(\mathrm{O})(\mathrm{OR})^{6-}$ where $\mathrm{R}={ }^{\mathrm{t}} \mathrm{Bu}$ and ${ }^{\mathrm{i}}$ Pr. J. Am. Chem. Soc. 1995, 117, 7428-7440.

64. Aime, S.; Arce, A.J.; Chiantore, O.; Gobetto, R.; Russo, A.; de Sanctis, Y. Ring-opening polymerisation of norbornene by $(\mu-\mathrm{H})_{2} \mathrm{Os}_{3}(\mathrm{CO})_{10}$ complex. J. Organomet. Chem. 2001, 622, 43-46.

65. Levisalles, J.; Rose-Munch, F.; Rudler, H.; Daran, J.-C.; Dromzée, Y.; Jeannin, Y. Dinuclear carbene complexes of tungsten as catalysts for metathetical polymerisation of alkenes and alkynes; X-ray crystal structure of the insertion product of but-2-yne into a $\mu$-alkylidene carbontungsten bond. J. Chem. Soc. Chem. Commun. 1981, 152-154.

66. Knox, S.A.R. 25 years with ruthenium. J. Organomet. Chem. 1990, 400, 255-272. 
67. Abraham, R.J.; Barlow, A.P.; Rowan, A.E. Substituent chemical shifts in NMR. Part $4-{ }^{1}$ H SCS in some 2-substituted norbornanes and bornanes. Magn. Res. Chem. 1989, 27, 1074-1084.

68. Dragutan, V.; Dragutan, I.; Dimonie, M. A Selective Route for Synthesis of Linear Polydicyclopentadiene. In Green Metathesis Chemistry: Great Challenges in Synthesis, Catalysis And Nanotechnology; Dragutan, V., Demonceau, A., Dragutan, I., Finkelshtein, E.S., Eds.; Springer: Dordrecht, The Netherlands, 2009.

69. Bokaris, E.P.; Kosmas, M.M. All cis-poly(NBE) derived by the ROMP catalysts based on $\mathrm{WCl}_{6}$. J. Mol. Catal. A Chem. 2003, 192, 263-273.

(C) 2012 by the authors; licensee MDPI, Basel, Switzerland. This article is an open access article distributed under the terms and conditions of the Creative Commons Attribution license (http://creativecommons.org/licenses/by/3.0/). 